Article

\title{
Overcoming Barriers to the Implementation of Cleaner Production in Small Enterprises in the Mechanics Industry: Exploring Economic Gains and Contributions for Sustainable Development Goals
}

\author{
Geraldo Cardoso de Oliveira Neto ${ }^{1,2,3}{ }^{\mathbb{D}}$, Roberto Rodrigues Leite ${ }^{1,4}$, Wagner Cezar Lucato ${ }^{1}$, \\ Rosangela Maria Vanalle ${ }^{1}$ (D), Marlene Amorim ${ }^{2,3, *(\mathbb{D})}$, João Carlos Oliveira Matias ${ }^{2,3}$ and Vikas Kumar ${ }^{5}$ (D)
}

Citation: Neto, G.C.d.O.; Leite, R.R.; Lucato, W.C.; Vanalle, R.M.; Amorim,

M.; Matias, J.C.O.; Kumar, V.

Overcoming Barriers to the Implementation of Cleaner Production in Small Enterprises in the Mechanics Industry: Exploring Economic Gains and Contributions for Sustainable Development Goals Sustainability 2022, 14, 2944 https://doi.org/10.3390/su14052944 Academic Editor: Marc A. Rosen

Received: 30 December 2021 Accepted: 23 February 2022 Published: 3 March 2022

Publisher's Note: MDPI stays neutral with regard to jurisdictional claims in published maps and institutional affiliations.

Copyright: (C) 2022 by the authors. Licensee MDPI, Basel, Switzerland. This article is an open access article distributed under the terms and conditions of the Creative Commons Attribution (CC BY) license (https:// creativecommons.org/licenses/by/ $4.0 /)$.
1 Industrial Engineering Post-Graduation Program, Universidade Nove de Julho (UNINOVE), Sao Paulo 01504-001, Brazil; geraldo.prod@gmail.com (G.C.d.O.N.); rodlei@bol.com.br (R.R.L.); wagner.lucato@gmail.com (W.C.L.); rvanalle@uni9.pro.br (R.M.V.)

2 GOVCOPP, Unidade de Investigação em Governança, Competitividade e Políticas Públicas, University of Aveiro, 3810-193 Aveiro, Portugal; jmatias@ua.pt

3 DEGEIT, Departamento de Economia, Gestão, Engenharia Industrial e Turismo, University of Aveiro, 3810-193 Aveiro, Portugal

4 Production Engineering Post-Graduation Graduation Program, Faculdades Metropolitanas Unidas (FMU), São Paulo 4020-050, Brazil

5 Bristol Business School, University of the West of England, Bristol BS16 1QY, UK; vikas.kumar@uwe.ac.uk

* Correspondence: mamorim@ua.pt

\begin{abstract}
The purpose of this study is to evaluate the economic and environmental gains that result from the implementation of cleaner production in a small enterprise (SE) from the metal and mechanics industry, allowing for overcoming barriers and contributing to sustainable development goals. The research work builds on a case study that involved several data sources, including semi structured interviewing and non-participant observation. Data analysis involved the calculation of mass balance, building solid and liquid waste that were minimized in the process. The results suggest that cleaner production led to economic gains, by allowing for reduction in losses and promoting a better use of raw materials. It also led to environmental improvements by means of the implementation of a wastewater treatment station that allowed for the reuse of water in the manufacturing process. It was concluded that the economic gain in the project played a determinant role for the SE to overcome the barriers for the implementation of $\mathrm{CP}$ and leading to the reduction of the environmental impact in the abiotic, biotic, water and air compartments, as estimated with the Mass Intensity Factor. The study offers a timely and relevant contribution for the literature in the field, while offering insights for o managerial practice, and the attainment of the Sustainable Development Goals defined by the United Nations Development Program.
\end{abstract}

Keywords: economy and environmental advantage; cleaner production barriers; cleaner production; metal mechanics industry; sustainable development goals

\section{Introduction}

Small enterprises (SEs), defined here as companies with an annual turnover $\leq$ EUR 10 million [1], play an important role in the world Economy. Despite of the acknowledged importance of SEs, only recently they have started to receive adequate attention in the academic literature [2]. The socio-economic relevance of SE is attributed to several factors including its role in the promotion of social development and economic stability, that are fundamental to support political stability and job creation.

Several environmental problems that are associated with the operations of SE have been highlighted in recent years. In the specific context of the mechanics industry some of 
them are deemed as complex given the high costs that are involved in any investments that are required to adopt clean technologies, as well as for the treatment and disposal of waste.

To a great extent, the management of SE is characterized by the prevalence of a short run perspective. Moreover, there is a substantial diversity in the flows of waste that are generated that requires the implementation of very differentiated strategies in order to implement any reduction and reutilization practices, therefore creating important managerial difficulties. In recent years, the economic development and the aggravation of environmental problems has been triggering the pursuit of solutions to address such challenges faced by SEs. These enterprises aim for cost effective solutions to reduce their environmental impact, and therefore engage on activities that allow the reengineering of their products and processes in order to make them more efficient in the utilization of resources while reducing the volumes of waste [3,4].

The SEs operating in the mechanics industry act was suppliers for other economic activities across the value chain in several industries, such as the automotive sector and the construction industry. They are responsible for an important volume of negative impacts over the environment concerning the levels of pollution generated by their activities, as well as for their intense consumption of raw materials, and the risks associated with the disposal of production waste [5].

According to [6], one of the key challenges is the need to align the economic growth with the objectives of contributing to cleaner and sustainable environmental conditions. Against this background, the paradigm of Cleaner Production (CP) stands out as a strategy that is economically viable to reduce the environmental impact of production systems, offering superior performance for environmental protection and reducing the risks for humans by focusing on the reduction of the volumes of waste that are generated [7]. The core principle of $\mathrm{CP}$ is the efficient use of natural resources and energy, and the reduction of risks and impacts for humans and the environment throughout the life cycle of a product [8]. According to the perspective inscribed in the Sustainable Development Goals proposed by the United Nations, energy audits can increase the opportunities for companies to achieve higher standards of energy efficiency [9].

The implementation of CP practices leads to more competitiveness of SEs, increasing the quality of their products, and offering alternatives for achieving improvements in the environmental performance, reducing costs, and allowing for the creation of opportunities for new products development and new business opportunities [10]. The results achieved with CP can be assessed using the methodology proposed by [11] involving the monitoring of environmental indicators that must address relevant information, allowing for a better understanding of the production process impacts, and for the evaluation of the impacts of $\mathrm{CP}$ in the environmental performance of the company.

Despite the benefits that are attributed to $\mathrm{CP}$, its rate of implementation is still modest in SEs. This is usually attributed to factors related to the lack of resources, and the limitations in decision making that are associated to the concentration of managerial responsibilities in the hands of the owners, and often to the lack of leadership capabilities [12]. Other limitations that are often advanced to explain the low implementation of CP in Ses include the lack of financial resources to invest in technologies for the reduction of waste and emissions, as well as the lack of qualified human resources and infrastructure problems $[13,14]$.

Existing research about the implementation of CP in the metal and mechanics sector refers to the opportunity of achieving economic gains supported by the estimation of the returns on investment (ROI) $[15,16]$. In what concerns the minimization of the environmental impact, several studies mention the existence of evidence of improvements, despite not offering an explicit quantitative measurement for them $[17,18]$. Some studies use the mass balance method to determine and quantify the reduction in the consumption of raw materials and the reduction in waste. However, the studies do not offer quantitative data for the environmental impact [16,19]. Other studies offer data in relative terms to demonstrate the reductions in losses, but do not assess the environmental impact of such losses $[5,20,21]$. 
Only one study, conducted with a Brazilian SE in the metal mechanic sector, showed that the cultural and technical barriers have negative impacts for the adoption of CP. Such barriers can be overcome by economic and environmental gains though investments in the training of employees and in the acquisition of more efficient machinery and equipment [22]. However, this research did not identify any previous work addressing the SDGs by implementing environmental actions to overcome $\mathrm{CP}$ barriers. Sustainable development needs to become the key goal of environmental actions to overcome $\mathrm{CP}$ barriers. The SDGs aim to allow for meeting the needs of the society by means of an intelligent use of sustainable science [23,24].

This study subscribes to the need of assessing the environmental impacts at several levels, including biotic, abiotic, air and water as environmental actions for overcoming barriers for $\mathrm{CP}$, and therefore contributing to attain the SGDs. Accordingly, the study assessed the reduction in the environmental impact building on the Mass Intensity Factor (MIF) instrument [25]. As such, the first research question of this study, is formulated as follows: How can the reduction in environmental impacts for the biotic, abiotic, air and water elements, lead to overcoming the barriers to the implementation of $\mathrm{CP}$ and contribute to attain the SDGs?

Another research gap that was identified concerns the lack of studies offering quantitative evidence about the process of overcoming the barriers for the adoption of $\mathrm{CP}$, while connecting it with the SDGs. Existing work related to the barriers for the adoption of $\mathrm{CP}$ in SEs in the metal and mechanics sector usually refer to the SDGs but fail to address the economic, social and environment aspects with an equivalent depth [26]. Companies consider the that the specific limitations of SEs are determinant for the ability to understand the barriers for the adoption of $\mathrm{CP}$ and highlight that such limitations affect the ability to access relevant knowledge and information for overcoming the barriers. A lack of understating of the benefits that result from the adoption of CP persists [14,27].

$\mathrm{CP}$ practices are attributed a great importance for the achievement of sustainable development [28]. The work of [29-31] concluded that CP practices lead to relevant economic and environmental results. SEs have a focus on production management problems, often disregarding environmental factors, due to the pressure they face for meeting short run objectives, together with the lack of resources [16,32]. These companies usually do not have enough human resources with the necessary technical capabilities, nor departments that are adequately focused on innovation $[14,33]$. Such factors are important for the identification of the barriers to the implementation of $\mathrm{CP}$ and are the key for pursuing alternatives for sustainable solutions for their products and processes [4,27,32]. Very often, SEs face financial difficulties that are associated with lack of knowledge about the returns on the investment. As such, the knowledge about the economic gains that could be achieved by SEs, would mitigate the financial barriers, and would contribute to the attainment of SDGs. This leads to the second research question of this study: How can economic gains lead to overcoming the barriers for the adoption of $\mathrm{CP}$, and contribute to attain the SDGs?

As such, one of guiding objectives of this study was to evaluate the economic and environmental gains that resulted from the implementation of $\mathrm{CP}$ in a small enterprise in the metal and mechanics industry, allowing for overcoming barriers and contributing to the SDGs. It is important to highlight that there are few studies relating $\mathrm{CP}$ with the SDGs $[9,23,26,28,29]$. However, sustainable development must be considered as a key issue in the adoption of $\mathrm{CP}$ [34], particularly when it allows for extending the $\mathrm{CP}$ practices to the stakeholder community $[35,36]$. As aforementioned, existing studies focus in addressing the economic and environmental gains mostly from a qualitative perspective. Existing work builds on: cost-benefit analysis [37]; the improvement in the use of resources and the efficiency in materials [38]; the recycling and the reuse of waste [39]; the reduction in the consumption of raw materials and inputs and the minimization of the volume of waste generated [40-42]; the improvements in the use of resources [43,44]; the reduction of emissions [45,46]; and the adoption of clean technologies [47,48]. This is the first study that addresses economic and environmental gains and the overcoming of barriers for 
the adoption of $\mathrm{CP}$, while contributing to SDGs. The article is organized in five sections, including the introduction, a section devoted to the description of materials and methods, the results, a discussion and a conclusion.

\section{Materials and Methods}

According to [49], the case study method is adequate when the research question is ample and complex, and the existing knowledge is insufficient. Likewise, case study is recommended when the phenomena to investigate cannot be addressed outside of its natural context. As such, case studies allow for exploratory research in a domain for which the number of studies is still limited. Case study allows for the development of contributions to theory development, building on empirical observation.

The evidence for a case study can be derived from several sources, including documents, archival data, interviews, direct observation, participant observation and physical artefacts [49]. Accordingly, and building on the research questions that were put forward, a case study was conducted allowing to shed light into the subject with an applied case and allowing for a rich understanding of the phenomena [49]. The sources of evidence used in the study included: archival data, semi-structured interviews and nonparticipant observation. These methods allowed for the collection of qualitative and quantitative data [50]. The semi-structured interview was conducted with the production manager and supervisor of the company. Interviews are considered key instruments for the conduction of case studies [51,52]. Observation was conducted in the production process. The desk research resorted also to the electronic archives supplied by the company, referring to elements such as the volumes of waste, the consumption of raw materials, the costs associated with waste disposal and related information, therefore offering valuable data to complement the information collected in the interview, and allowing for gathering qualitative and quantitative data [53].

The study was conducted in a Brazilian SE belonging to the metal and mechanics sector. This company was chosen in face of some peculiar characteristics: it had implemented several $\mathrm{CP}$ practices that allowed the researchers to explore their effect on the economic and environmental areas and it allowed the investigators complete access to the data required to perform the necessary studies and analyses.

In the field research, a first phase involved asking the respondents to attribute a weight to rate the relative importance of the barriers identified in the literature (Table 1). The barriers with higher importance were rated with 10 points.

Table 1. Barriers to the implementation of CP.

\begin{tabular}{|c|c|c|c|}
\hline Barriers & $\begin{array}{l}\text { Ratting Attributed by } \\
\text { the Specialist }\end{array}$ & Concept & References \\
\hline Economic and financial & 10 & $\begin{array}{l}\text { Lack of economic resources for investing in } \\
\text { environmental actions }\end{array}$ & {$[3,13,14,27,30,46-48]$} \\
\hline Cultural & 9 & $\begin{array}{l}\text { Lack of knowledge and difficulties in } \\
\text { accessing information }\end{array}$ & {$[14,18,27,30,32]$} \\
\hline Governmental & 2 & Public policies for the implementation of $\mathrm{CP}$ & {$[3,14,27,30,31,46]$} \\
\hline Organizational & 2 & Risk of survival of the enterprise & {$[3,14,27]$} \\
\hline Technical & 10 & Lack of professional capabilities & {$[3,10,13,27,30-32,46,47]$} \\
\hline Market & 1 & $\begin{array}{l}\text { Low perceptions from customers, suppliers, } \\
\text { and competitors about the adoption of } \mathrm{CP}\end{array}$ & {$[10,27,30,31]$} \\
\hline Social & 2 & Lack of social awareness & {$[14,30]$} \\
\hline Behaviour & 3 & Lack of commitment & {$[3,13,27,32]$} \\
\hline Technologic & 10 & Obsolete equipment and tools & {$[3,13,32,48]$} \\
\hline
\end{tabular}


After the data collection phase, the next stage involved the evaluation of the economic and environmental results of the implementation of $\mathrm{CP}$, to address the proposed research questions. The instruments used to evaluate the economic and environmental results, as recommended by [34,54-59] followed the methodology for the environmental evaluation of the implementation of Eco efficiency tools in industrial operations. A first step involved the collection of data to identify the reduction in waste and emissions, by means of a mass balance method, offering detail about the materials and the components and calculation of the Total Saved Materials (MTE). The data about the waste and emissions allowed for measuring the economic and environmental results. Next, the mass balance was computed with the purpose of identifying economic gains. Returns were also calculated for any investments made. The evaluation of the environmental gain followed using the Equation (1) for Mass Intensity Factors (MIF). For this purpose, the study considered the Mass (M) and the Intensity Factor (IF), using Equation (2) next for obtaining the Mass Intensity per Compartment (MIC). It measured the reduction in the environmental impact for each abiotic compartment (w), biotic (x), water (y), air (z) and other (n...). This allows for the quantification, using Equation (3) of the reduction in the total impact, Mass Intensity Total (MIT) that brings together all the MICs.

$$
\begin{gathered}
\mathrm{MIF}=\mathrm{M} \times \mathrm{IF} \\
\mathrm{MIC}=(\mathrm{w}+\mathrm{IF})(\mathrm{x}+\mathrm{IF})(\mathrm{y}+\mathrm{IF}) \\
\mathrm{MIT}=(\mathrm{MICw}+\mathrm{MICx}+\mathrm{MICy}+\mathrm{MICz}+\mathrm{MICn} \ldots)
\end{gathered}
$$

The values for MIF presented in Table 2 represent the intensity factors used in the study, according to the specified by the relevant entity [60].

Table 2. Intensity Factor for the Materials addressed in the study.

\begin{tabular}{llcccc}
\hline \multicolumn{1}{c}{ Component } & \multicolumn{1}{c}{ Specification } & Abiotic & Biotic & Water & Air \\
\hline Aluminium & Secondary & 0.85 & 0 & 30.74 & 0.95 \\
Aluminium chloride & $\mathrm{AICI} 3$ & 8.61 & 0 & 110.63 & 1.15 \\
Lead & $\mathrm{Pb}$ & 15.6 & 0 & 0.00 & 0.00 \\
Copper & $\mathrm{Secondary-Cu}$ & 2.38 & 0 & 85.51 & 1.32 \\
Nickel & $\mathrm{Ni}$ & 141.29 & 0 & 233.34 & 40.83 \\
Tin & $\mathrm{Sn}$ & 8468.00 & 0 & $10,958.00$ & 149.00 \\
Water & $\mathrm{H} 2 \mathrm{O}$ & 0.01 & 0 & 1.30 & 0.001 \\
Lime & Virgin & 1.44 & 0 & 5.56 & 0.03 \\
Electrical power & Industrial & 2.67 & 0 & 37.92 & 0.64 \\
Chlorine & $\mathrm{Cl} 2$ & 3.84 & 0 & 10.9 & 1.09 \\
Oil & Hu, 42.8 MJ/kg & 1.36 & 0 & 9.7 & 0.02 \\
Carbon steel & Secondary & 8.14 & 0 & 63.67 & 0.44 \\
\hline Source: Adapted with permission from [60]. & & & &
\end{tabular}

The data collected in the case study allowed for the presentation of economic results and motivated the company to continue to work towards overcoming the barriers to $\mathrm{CP}$, while providing information for the evaluation of the reduction of its environmental impact.

\section{Analysis and Discussion of the Case Study Evidence}

The company addressed in the study is classified as a small enterprise, involving 68 direct employees. The company is located in the City of São Paulo, Brazil, and its Production is targeted to the automotive sector, white line appliances and big auto parts wholesalers. The company is an ISO 9001:2015 certified company, that produces blind rivets, solid tubular nucleuses and drawn wire, using cold forming with materials such as steel, carbon and aluminium. In what concerns the requirements for environmental legislation the company addressed in the study meets the prevalent standards regarding the disposal of contaminant waste, and the noise levels released by the manufacturing unit, 
an aspect that was particularly relevant due to the proximity of the factory to an urban residential area. The findings exhibited in Table 1 suggest that the main barriers associated with the implementation of $\mathrm{CP}$ in this $\mathrm{SE}$ are related with the lack of economic resources for investing in environmental actions; the lack of qualification and training of the human resources; and the use of obsolete equipment and tools, leading to the generation of waste. It was also observed that cultural barriers have negative impacts for the implementation of $\mathrm{CP}$ due to the lack of knowledge and low employee awareness about environmental issues.

\subsection{Process Analysis}

The identification of the polluting load generated by the company involved multiple observations of the production processes devoted to the production of aluminium wire and aluminium and steel fasteners. The research work also involved the examination of administrative documents such as reports for the wastewater treatment plant, and documents concerning the control of waste disposal activities, for solids and liquid waste.

In the production process for the fasteners the components are made in aluminium by means of cold forming processes using drawing mills and horizontal presses. Each month, an average of 50 tons of steel wire and 12 tons of aluminium wire are used, for an average monthly production of 45 million fasteners. The loss in raw materials in these first stages of the production process was around 2 tons of steel and 0.8 tons of aluminium per month. The implementation of $\mathrm{CP}$ led to a reduction in the loss index to 1.3 tons of steel and 0.5 tons of aluminium per month. These materials were then stored adequately and sent for recycling, periodically.

The fabrication of the fasteners uses cutting oil that becomes impregnated in the surface of the components and is separated by means of spinning, with the purpose of being reused. Not all the oil is effectively removed in this first phase of cleaning, so the parts are next washed with hot degreasing so that they can proceed to thermal treatment and polishing. For a long time, all the effluents generated in the thermal treatment and polishing sectors were discarded in in the public sewage. However, to meet the environmental legislation the company installed a Wastewater Treatment Station (ETE) providing a treatment for the wastewaters generated in the production process. For the implementation of the ETE the company invested about USD 59,000 including the costs for the project, equipment, and lab analysis, as well as in training and awareness programs for the employees.

The implementation of the wastewater treatment station, that aimed at achieving standard levels for the concentration of impurities in the residual waters-as specified by the prevalent legislation-involved several phases, including: (a) the conduction of treatability tests (Jar Test) to determine the volume of flocculants and coagulants, reducing the concentrations for metals, oils and grease; (b) the implementation of a separating box (for water and oils); (c) the implementation of a homogenising system with air; (d) the installation of a tank for the preparation of solutions; (e) the installation of tank for mixing and $\mathrm{pH}$ calibration; (f) the installation of a decanter tank for solid metals. The local environmental legislation establishes the following requirements for wastewaters that are discarded from the ETE: $\mathrm{pH}$ ranging between 6.0 and 10; temperature below to $40{ }^{\circ} \mathrm{C}$; concentration of sediments up to $20 \mathrm{~mL} / \mathrm{L}$ in nine hour testing using a Inhof cone; absence of grease and oils, a concentration of $150 \mathrm{mg} / \mathrm{L}$ of soluble substances in hexane; absence of explosive or flammable substances; absence of substances that can cause clogging in pipes; absence of any substances in concentrations that can be toxic for biological processes.

In the first phase, that was devoted to the data collection, an annual mass balance was estimated, building on the Mass (M) of solid residues, liquids and emissions generated in the manufacturing processes and in the wastewater treatment station (ETE), that were minimized with the implementation of CP. This allowed for the reduction in the environmental impact, as displayed in Table 3. 
Table 3. Intensity Factors for the Materials used in the study.

\begin{tabular}{llccc}
\hline \multicolumn{1}{c}{ Components } & \multicolumn{1}{c}{ Classification } & Local & Unit (Monthly) & $\begin{array}{c}\text { Annual Waste } \\
\text { (kg) }\end{array}$ \\
\hline Aluminium & Secondary & & $0.3 \mathrm{mg} / \mathrm{kg}$ & 0.003744 \\
Aluminium chloride & $\mathrm{AICI}_{3}$ & & $0.3 \mathrm{mg} / \mathrm{kg}$ & 0.003744 \\
Lead & $\mathrm{Pb}$ & & $9.68 \mathrm{mg} / \mathrm{kg}$ & 0.1208064 \\
Copper & $\mathrm{Cu}$ & & $17 \mathrm{mg} / \mathrm{kg}$ & 0.21216 \\
Nickel & $\mathrm{Ni}$ & Wastewater Treatment & $11 \mathrm{mg} / \mathrm{kg}$ & 0.13728 \\
Tin & $\mathrm{Sn}$ & Station (ETE) & $36 \mathrm{mg} / \mathrm{kg}$ & 0.44928 \\
Water & $\mathrm{H}_{2} \mathrm{O}$ & $192 \mathrm{~m} 3$ & $1,920,000$ \\
Lime & $\mathrm{Limestone}$ & & $140 \mathrm{~kg}$ & 1680 \\
Electrical power & $\mathrm{Kw}$ & & $15 \mathrm{kw}$ & 180 \\
Chlorine & $\mathrm{Cl}{ }_{2}$ & & $0.05 \mathrm{mg} / \mathrm{kg}$ & 0.00624 \\
Oil & $\mathrm{Hu}, 42.8 \mathrm{MJ} / \mathrm{kg}$ & $20 \mathrm{~kg}$ & 240 \\
Steel & $\mathrm{Secondary}$ & Manufacturing process & $700 \mathrm{~kg}$ & 8400 \\
Aluminium & $\mathrm{Secondary}$ & Manufacturing process & $300 \mathrm{~kg}$ & 3600 \\
\hline
\end{tabular}

With the implementation of $\mathrm{CP}$ in the wastewater treatment system, the company was able to reuse the water in its manufacturing process, complementing the ETE with the implementation of the necessary units for the polishing. These included: systems for membrane filtration; chemical oxidation and disinfection to promote the separation between solid and liquid residues, by using continuous decanting for the precipitators, and also the correct destination for solid and liquid waste.

\subsection{Economic Evaluation}

The second phase of the study involved the conduction of the annual economic evaluation. To start with, an investment of about USD 35,000 was made in the manufacturing process to implement $\mathrm{CP}$, as well as an in the wastewater treatment station of USD 15,400, for the acquisition of equipment for water reuse in the production system.

The data presented in Table 4 provides evidence about the increase that was registered in the operational expenses, due to the implementation of the wastewater treatment station. Such expenses are related to the increase in the use of chemicals for the treatment of the effluents, as well as for the energy consumption that is necessary to operate the pumps and the lab analysis that had to be subcontracted. The training of employees also involved an investment of about USD 5000, to guarantee the adequate capabilities to operate the ETE. To this end, the quality department also added the function of cleaning the system, the handling of chemicals, and the removing of the sludge that is generated in the process, for disposal. Quotation was done for subcontracting the lab tests for the residues, with the purpose of issuing the necessary documents for the transport and the disposal of the sludge. Meanwhile, a reduction in the consumption of water was observed, after the implementation of CP from a volume of $4320 \mathrm{~m}^{3}$ /year to $2400 \mathrm{~m}^{3}$ /year, resulting in a total of USD 44,856 of savings. This represented $58 \%$ of the water reuse in the production system. A gain of $66 \%$ was also observed due to the reduction in the waste of raw materials in the manufacturing of fasteners of steel and aluminium. The volume of such waste reductions was from about 24,000 kg each year to $15,600 \mathrm{~kg}$, for the steel, and from $9600 \mathrm{~kg}$ to $6000 \mathrm{~kg}$ for the aluminium, leading to an overall gain of USD 78,000. As such, a total economic gain of BRL 112,031 was attained, as displayed in Table 4. 
Table 4. Economic Gains from implementation of CP.

\begin{tabular}{lcc}
\hline \multicolumn{1}{c}{ Items } & $\begin{array}{c}\text { Annual Expenditure-without } \\
\text { CP (US\$) }\end{array}$ & $\begin{array}{c}\text { Annual Expenditure-with } \\
\text { CP (US\$) }\end{array}$ \\
\hline Chemicals & 1200 & 2640 \\
Lime & 180 & 180 \\
Activated carbon & 180 & 180 \\
Sand & 600 & 600 \\
Electrical power & 960 & 1440 \\
Human resources & 7200 & 7200 \\
Lab tests & 3000 & 11,904 \\
Disposal certificate & 1000 & 1000 \\
Transport of waste & 600 & 600 \\
Destination & 2496 & 2496 \\
Water & 106,800 & 61,944 \\
Total for ETE & 124,216 & 90,184 \\
Gains/capital for ETE & & 34,031 \\
Waste-steel & 84,000 & 54,000 \\
Waste-aluminium & 144,000 & 96,000 \\
Total Manufacturing & 228,000 & 150,000 \\
Gains/Capital Manufacturing & & 78,000 \\
Economic Gain & & 112,031 \\
\hline
\end{tabular}

The measurement of the return on investment for the implementation of $\mathrm{CP}$ took into account the investment in the manufacturing process-USD 35,000; the investment in the wastewater treatment station-USD 15,400; and the investment of USD 5000 in training, adding up to USD 55,400, considering a 10-year depreciation. The estimation also considered the reduction that was observed in the annual costs-USD 112,031-and an Income tax rate of $30 \%$. This leads to an annual cash generation of USD 80,083. As such, the capital invested will be totally recovered after one year.

Furthermore, it was possible to measure the economic advantage that the company obtained with the implementation of $\mathrm{CP}$. The economic and financial gains allowed to make up for the lack of resources for the investment in environmental actions, given the need for training and the acquisition of clean equipment.

The training offered to the employees contributed also for the reductions in the consumption of energy, raw materials, oils and chemicals, in addition to minimizing the generation of solid waste. A wastewater treatment station was also implemented, leading to the reduction in the consumption of water.

Against this background, by overcoming the economic, technical and technological barriers, several contributions were achieved for the attainment of the SDGs. These included: (i) for SDG 6, the impacts for the use of water and basic sanitation by allowing for reductions in the consumption of water due to the implementation of the wastewater treatment station; (ii) for SDG 9 that relates to the innovation and infrastructure, with the implementation of $\mathrm{CP}$ and the development of the wastewater treatment station; (iii) for SDG 12, concerning the sustainable production and consumption, through the reductions in the consumption of energy, water, oils and chemicals, and the minimization of the generation of solid waste.

\subsection{Environmental Evaluation}

In the third stage of the study the environmental gains associated with the implementation of $\mathrm{CP}$ were evaluated. In Table 5 we offer a view of the material intensity for each compartment (MIC) and the total material intensity (MIT). The results show that the enterprise reduced the consumption 97,696 $\mathrm{kg}$ for the abiotic compartment, 3,165,071 kg for water and $9279 \mathrm{~kg}$ for air, resulting in a total environmental gain (GA) 3,272,048 kg. A key issue concerns the water reuse that was made possible by the implementation of the 
wastewater treatment station that led to a reduction in consumption of natural resources of $2,517,120 \mathrm{~kg}$.

Table 5. Environmental evaluation.

\begin{tabular}{|c|c|c|c|c|c|c|}
\hline \multirow{2}{*}{ Component } & \multirow{2}{*}{ Sector } & \multicolumn{4}{|c|}{ Compartments } & \multirow{2}{*}{$\begin{array}{c}\text { Total by } \\
\text { Component }\end{array}$} \\
\hline & & Abiotic & Biotic & Water & Air & \\
\hline Aluminium & \multirow{14}{*}{$\begin{array}{l}\text { Wastewater } \\
\text { Treatment Plant }\end{array}$} & 0.00319 & & 0.1151 & 0.0036 & 0.12189 \\
\hline Aluminium chloride & & 0.0323 & & 110.63 & 0.4142 & 111.0765 \\
\hline Lead & & 1.885 & & & & 1.885 \\
\hline Copper & & 0.505 & & 18.141 & 0.28 & 18.926 \\
\hline Nickel & & 19.396 & & 32.033 & 5.605 & 57.034 \\
\hline Tin & & 3812.59 & & 4923.21 & 66.943 & 8802.743 \\
\hline Water & & 19,200 & & $2,496,000$ & 1920 & 2517,120 \\
\hline Lime & & 2419.20 & & 9340.80 & 50.4 & $11,810.4$ \\
\hline Electrical power & & 480.6 & & 6825.60 & 115.2 & 74,214 \\
\hline Chlorine & & 0.024 & & 0.63 & 0.0068 & 0.6608 \\
\hline Oil & & 326.4 & & 2328 & 4.8 & 2659.2 \\
\hline Steel & & 68,376 & & $534,828.00$ & 3696 & 606,900 \\
\hline Aluminium & & 3060 & & $110,664.80$ & 3420 & $117,144.8$ \\
\hline $\begin{array}{l}\text { Mass Intensity per } \\
\text { compartment (MIC) }\end{array}$ & & $97,696.64$ & & $3,165,071.96$ & 9279.65 & \multirow[t]{2}{*}{$3,272,048.25$} \\
\hline Mass Intensity Total (MIT) & & & & & & \\
\hline
\end{tabular}

The last stage of the study concerned the comparison between the economic and environmental gains. Data suggests that the total saved materials (MTE), considering the solids and liquids that were minimized of 1,934,101 kg, that corresponds to 3,272,048 $\mathrm{kg}$ when considering the total material intensity in the ecosystem. This data allows for determining the Eco efficiency levels.

For SEs the economic gains are the most relevant for overcoming most of the barriers. However, this study shows that the minimization of environmental impacts also contributes to overcoming cultural barriers. The study documents that the awareness activities about the environmental gains, that were conducted with the employees, had positive impacts. As such there is evidence of contributing for the SGD 15 concerning the ecosystems and the biodiversity associated with the environmental impacts from the abiotic, biotic, water and air compartments.

\section{Discussion and Contributions}

The results of the study suggest that the economic and financial barriers are among those that most hinder the implementation of $\mathrm{CP}$ in a SE. This is largely explained by the lack of resources for the investments in new technologies, as well as by the difficulties in accessing financing and the lack of qualification of employees in the specific domain of environmental issues. The economic factor emerges as the key obstacle for the SEs in the metal and mechanics sector when called for decision making and implementation of environmental practices. Former studies highlight the economic determinants as key obstacles that are hard to overcome [27,44]. The study supports that the achievement of an economic gain is a key requirement for the survival of SEs and that its investments are targeted to increase the production capabilities often disregarding the environmental factors. To invest in environmental actions, SEs need to have evidence of economic returns. Otherwise, such investments will very likely not occur, even if there is a growing understating about the environmental issues, its importance to the strategy of the company and for the achievement competitive differentiation. Several authors have also highlighted the importance of CP for sustainability [29].

The study illustrates how the economic factors have a direct and indirect influence for overcoming the barriers for the adoption of CP. The strategies described in the study to 
overcome the barriers to $\mathrm{CP}$ were derived from observing the combination of the economic benefits, the environmental impacts, and the implementation costs.

The project generated gains and savings for the company, suggesting the possibility of developing a stepwise strategy for the implementation of $\mathrm{CP}$ to reduce the financial burden that is usually associated with it. These results are aligned with [27] that affirm that given the specificities of SEs, some specific actions might be required to overcome the upfront barriers related with costs and with the lack of familiarity and knowledge about the implementation of $\mathrm{CP}$. The economic gains achieved by the company addressed in the study allowed for investments in the improvement of technical and professional elements, contributing for the motivation of employees and raising the awareness about the actions for the implementation of $\mathrm{CP}$. This result is also in accordance with the findings of [29] that observed that the $\mathrm{CP}$ barriers can be overcome with evidence of economic and environmental gains, and by means of investments in the qualification and training of employees, as well as in the acquisition of more efficient equipment.

In the work of [15], it is mentioned that the estimation of the volumes of waste and emissions is necessary for the effectiveness in the adoption of $\mathrm{CP}$ because there are many managers that are unaware of the opportunities to achieve financial gains from the adoption of CP. The studies of $[10,30]$ contributed to this argument by referring to the opportunity of achieving economic gains from the implementation of CP. However according to [37], CP is not thoroughly known in terms of cost-benefit analysis, and that most companies does not make a viable comparison between the environmental investments focused on the end line and the investments related with CP. This study is aligned with such findings in the literature and the organizational practice by demonstrating a substantial economic gain in the SE due to the reduction that was achieved in water consumption following the adoption of $\mathrm{CP}$ and the implementation of the wastewater treatment station, that allowed for the reuse of water in the manufacturing process. It was also possible to observe a reduction in the losses and in the waste by means of a better use of the raw materials leading to an overall economic gain of USD 112,031.

In this context the perspective of achieving economic gains triggered the company to adopt a CP approach and to pursuit the SDGs. The findings of the study are therefore aligned with theory, highlighting that economic gains can be an incentive to overcome barriers in the adoption $\mathrm{CP}$, and offering a first empirically documented support to this hypothesis. The study also offers a pragmatic contribution by describing and illustrating how to perform the economic assessment of the adoption of $\mathrm{CP}$, notably by addressing the estimation of the economic viability and offering an empirical basis for advancing the knowledge of the managers in this field.

The study also documented how obtaining economic gains with the adoption of $\mathrm{CP}$ in SEs can be associated with overcoming barriers on financial, technical and technological domains. The company invested in training for the employees and invested in new equipment leading to reduction in energy consumption, raw materials, oils and chemicals, while minimizing the generation of solid waste. The implementation of the wastewater treatment station was also determinant to reduce the water consumption.

Another relevant result offered by the study concerns the evaluation of the environmental impact at several levels including abiotic, biotic, water and air, while promoting the awareness about the damage that manufacturing can cause to the environment when there is a less cautious use of raw materials. Similar results were found in the work of $[23,24]$ that considers that microbiology can contribute for the attainment of a more sustainable future. There is still a paucity of research work addressing the relationship between the activities of SEs and the preservation of the environment, and a lack of evidence about solutions that can be applied and that lead to both economic and environmental gains. For this reason, several authors have claimed that the environmental actions are still far from being a reality for most of the SEs [12-14,26].

The study results led to the observation that it is necessary to perform the evaluation of the reduction in the environmental impact from several perspectives, including the biotic, 
abiotic, water and air, in order to fully capture the contributions for the attainment of SDGs. The assessment of the reduction in the environmental impacts was performed with the mass Intensity Facto (MIF) tool, offering, therefore, another relevant contribution to the advancing of the knowledge in this field, given the paucity of quantitative studies about the overcoming of barriers to $\mathrm{CP}$.

The actions implemented by the SE contributed for attainment of several DGS, as shown in Figure 1: SDG 6, concerning water and sanitation, by reducing the water consumption following the implementation of the wastewater station; SDG 9, associated with innovation and infrastructure by means of the minimization of the consumption of energy, raw materials, oils, chemicals and the minimization of solid waste. The reduction of environmental impacts, also contributed to overcome the cultural barriers, supported by the awareness actions that were implemented, therefore contributing to the SDG 15 that is related with ecosystems and biodiversity, with the reduction of environmental impact $t$ for biotic, abiotic, water and air compartments. This is the first study to address how economic and environmental gains contribute to overcome barriers to the implementation of $\mathrm{CP}$, for SEs, while evidencing the contributions for the SDGs.

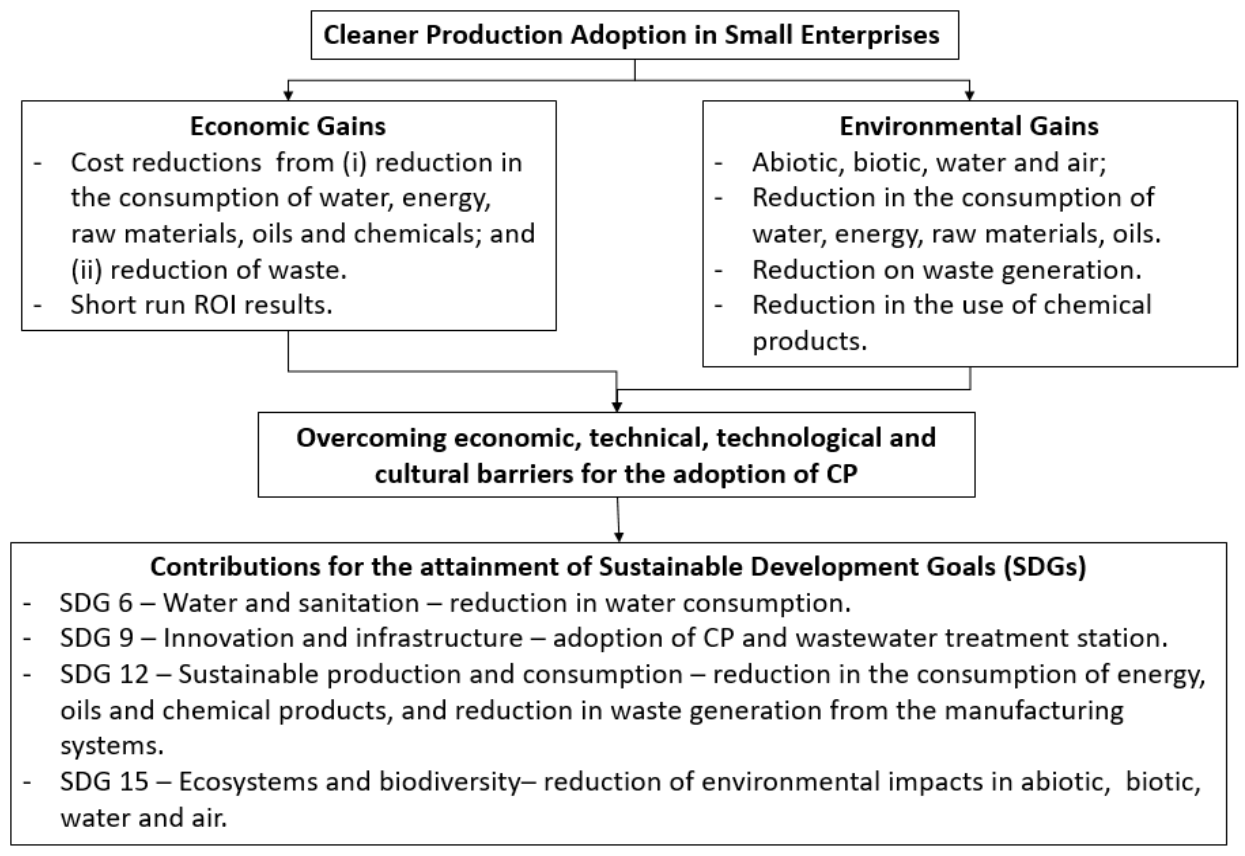

Figure 1. Contributions for the attainment of Sustainable Development Goals.

\section{Conclusions}

Besides the economic and environmental gains already reported herein, this research contributes for sustainability and for several of the SDG defined by the United Nations Development Program. Specific contributions were found for SDG 6 (water and sanitation), 9 (industry, innovation, and infrastructure), 12 (sustainable production and consumption) and 15 (ecosystems and biodiversity), as illustrated in Figure 1 above.

The results suggested by the study are relevant for the advancement in addressing the main barriers identified for the implementation of $\mathrm{CP}$, notably lack of resources for investments in $\mathrm{CP}$ and the lack of technical knowledge for the implementation of $\mathrm{CP}$.

Accordingly, the study puts forward that the SE from the metal and mechanics sector can work on developing plans and studies to assess the economic feasibility of implementation $\mathrm{CP}$ and obtain a financial return from it in the short run.

The study also offers a contribution for the academic literature and public policies about the adoption of $\mathrm{CP}$, its barriers, and its contribution for sustainability by offering a description of how to develop a project for implementing $\mathrm{CP}$, building on the economic 
and environmental evaluation. The study documents how such analysis contributed to overcoming the barriers for the implementation of CP usually pointed out for SEs, motivated by the potential economic gains and the reduction in environmental impacts. Likewise, the study also offers a contribution for managerial practice, notably in the domain of sustainability, by offering managers evidence about how environmental concerns can be addressed with the implementation of CP actions, by promoting the improvement of environmental conditions while generating economic gains with very attractive returns on investment.

The study is not free from limitations, notably because it offers an exploratory approach that builds on the analysis of a single case study. However, the study offers a timely and relevant contribution by illustrating the application of the methodology advanced for evaluating the economic and environmental impacts that are associated with the implementation of $\mathrm{CP}$, in an important industrial sector. Future replications and extensions of the study should address other industries and allow for cross-case comparison and generalizations.

Author Contributions: Conceptualization, R.R.L.; Data curation, G.C.d.O.N.; Formal analysis, R.R.L.; Investigation, W.C.L., M.A. and V.K.; Methodology, G.C.d.O.N. and R.M.V.; Project administration, G.C.d.O.N.; Validation, M.A. and J.C.O.M.; Writing-original draft, R.M.V. and M.A.; Writingreview \& editing, V.K. All authors have read and agreed to the published version of the manuscript.

Funding: This research received no external funding.

Institutional Review Board Statement: Not applicable.

Informed Consent Statement: Not applicable.

Data Availability Statement: Not applicable.

Conflicts of Interest: The authors declare no conflict of interest.

\section{References}

1. The European Commission. User Guide to the SME Definition; Publication Offices of the European Union: Luxembourg, 2016.

2. Carrera, N.; Trombeta, M. A pequena, vira grande! O papel das "pequenas" auditorias no estudo do mercado de auditoria, Revista. Rev. Contab. Finanças 2018, 29, 9-15. [CrossRef]

3. Severo, E.A.; Olea, P.M. Metodologias de Produção mais Limpa: Um Estudo de Caso no Polo Metal-Mecânico da Serra Gaúcha. INGEPRO-Inovação Gestão E Produção 2010, 2, 73-81.

4. Severo, E.A.; Dorion, E.C.H.; Olea, P.M.; Camargo, M.E.; Nodari, C.; Cruz, M.R. Cleaner production: Cases of the metal-mechanic automotive cluster of Serra Gaúcha, Brazil. Afr. J. Bus. Manag. 2012, 6, 10232-10237.

5. Yilmaz, O.; Anctil, A.; Karanfil, T. LCA as a decision support tool for evaluation of best available techniques (BATs) for cleaner production of iron casting. J. Clean. Prod. 2015, 105, 337-347. [CrossRef]

6. Khalili, N.R.; Duecker, S.; Ashton, W.; Chavez, F. From cleaner production to sustainable development: The role of academia. J. Clean. Prod. 2015, 96, 30-43. [CrossRef]

7. UNIDO/UNEP. Manual on the Development of Cleaner Production Policies-Approaches and Instruments. 2002. Available online: http:/ / www.unido.org/fileadmin/import/9750_0256406e.pdf (accessed on 10 March 2017).

8. Scarazzato, T.; Panossian, Z.; Tenorio, J.A.S.; Perez-Herranz, V.P.; Espinosa, D.C.R. A review of cleaner production in electroplating industries using electrodialysis. J. Clean. Prod. 2017, 168, 1590-1602. [CrossRef]

9. Munguia, N.; Esquer, J.; Guzman, H.; Herrera, J.; Gutierrez-Ruelas, J.; Velazquez, L. Energy E_ciency in Public Buildings: A Step toward the UN 2030 Agenda for Sustainable Development. Sustainability 2020, 12, 1212. [CrossRef]

10. Almeida, C.M.V.B.; Agostinho, F.; Giannetti, B.F.; Huisingh, D. Integrating cleaner production into sustainability strategies: An introduction to this special volume. J. Clean. Prod. 2015, 96, 1-9. [CrossRef]

11. PNUMA Programa das Nações Unidas para o Meio Ambiente. 2013. Available online: http://www.brasilpnuma.org/pordentro/ artigos_019.htm (accessed on 15 April 2017).

12. Nunes, J.R.R.; Ramos da Silva, J.E.A.; Moris, V.A.S.; Biagio, F.G. Cleaner Production in small companies: Proposal of a management methodology. J. Clean. Prod. 2019, 218, 357-366. [CrossRef]

13. Oliveira, J.F.G.; Alves, S.M. Adequação ambiental dos processos usinagem utilizando Produção mais Limpa como estratégia de gestão ambiental. Produção 2007, 17, 129-138.

14. Vieira, L.C.; Amaral, F.G. Barriers and strategies applying Cleaner Production: A systematic review. J. Clean. Prod. 2016, 113, 5-16. [CrossRef] 
15. Scavoneg, M. Challenges in internal environmental management reporting in Argentina. J. Clean. Prod. 2006, 14, 1276-1285. [CrossRef]

16. Duan, N.; Dan, Z.; Wang, F.; Pan, C.; Zhou, C.; Jiang, L. Electrolytic manganese metal industry experience-based China's new model for cleaner production promotion. J. Clean. Prod. 2011, 19, 2082-2087. [CrossRef]

17. Hernández, J.F.N. Cambio del proceso de decapado químico de acero por decapado mecánico. Prod. Más Limpia 2006,1 , 75-81.

18. Henriques, J.; Catarino, J. Sustainable Value and Cleaner Production e research and application in 19 Portuguese SME. J. Clean. Prod. 2015, 96, 379-386. [CrossRef]

19. Oliveira-Esquerre, K.P.; Kiperstok, A.; Mattos, M.C.; Cohin, E.; Kalid, R.; Sales, E.A.; Pires, V.M. Taking advantage of storm and waste water retention basins as part of water use minimization in industrial sites. Resour. Conserv. Recycl. 2011, 55, 316-324. [CrossRef]

20. Giraldo, A.M.C.; Giraldo, J.D.C. Mejoramiento em el manejo de los residuos sólidos en una industria metal mecánica. Prod. Más Limpia 2008, 3, 111-117.

21. Lilja, R.; Liukkonen, S. Industrial hazardous wastes in Finland e trends related to the waste prevention goal. J. Clean. Prod. 2008, 16, 343-349. [CrossRef]

22. Leite, R.; Amorim, M.; Rodrigues, M.; Oliveira Neto, G. Overcoming Barriers for Adopting Cleaner Production: A Case Study in Brazilian Small Metal-Mechanic Companies. Sustainability 2019, 11, 4808. [CrossRef]

23. Akinsemolu, A.A. The Role of Microorganisms in Achieving the Sustainable Development Goals. J. Clean. Prod. 2018, 182, 139-155. [CrossRef]

24. Sun, Y.; Xu, J. Evaluation Model and Empirical Research on the Green Innovation Capability of Manufacturing Enterprises from the Perspective of Ecological Niche. Sustainability 2021, 13, 11710. [CrossRef]

25. Ritthoof, M.; Rohn, H.; Liedtke, C. Calculating MIPs, Resources Productivity of Products and Services. Available online: http: / / www.wupperinst.org/uploads/tx_wiberitrag/MIT_v2.pdf (accessed on 2 April 2017).

26. Giannetti, B.F.; Agostinho, F.; Almeida, C.M.V.B.; Liu, G.; Contreras, L.E.V.; Vandecasteele, C.; Coscieme, L.; Sutton, P.; Poveda, C. Insights on the United Nations Sustainable Development Goals scope: Are they aligned with a 'strong' sustainable development? J. Clean. Prod. 2019, 252, 119574. [CrossRef]

27. Klewitz, J.; Hansen, E.G. Sustainability-oriented innovation of SMEs: A systematic review. J. Clean. Prod. 2014, 65, 57-75. [CrossRef]

28. Giannetti, B.F.; Agostinho, F.; Eras, J.J.C.; Yang, Z.; Almeida, C.M.V.B. Cleaner production for achieving the sustainable development goals. J. Clean. Prod. 2020, 271, 122127. [CrossRef]

29. Oliveira Neto, G.C.; Correia, J.M.F.; Silva, P.C.; Sanches, A.G.O.; Lucato, W.C. Cleaner Production in the textile industry and its relationship to sustainable development goals. J. Clean. Prod. 2019, 228, 1514-1525. [CrossRef]

30. Park, W.; Byun, C. Effect of SME's Managerial Ability and Executive Compensation on Firm Value. Sustainability 2021, 13, 11828 [CrossRef]

31. Silva, A.L.E.; Morales, J.A.R.; Machado, E.L. Proposta de produção mais limpa voltada às práticas de ecodesign e logística reversa. Eng. Sanitária E Ambient. 2015, 20, 29-37. [CrossRef]

32. Sissino, C.L.S.; Moreira, J.C. Ecoeficiência: Um instrumento para a redução da geração de resíduos e desperdícios em estabelecimentos de saúde. Cad. Saúde Pública 2005, 21, 1893-1900. [CrossRef]

33. Severo, E.A.; Guimarães, J.C.F.; Dorion, E.C.H.; Nodari, C.H. Cleaner production, environmental sustainability and organizational performance: A empirical study in the Brazilian Metal-Mechanic. J. Clean. Prod. 2015, 96, 118-125. [CrossRef]

34. Cong, W.; Shi, S. Heterogeneity of industrial development and evolution of cleaner production: Bibliometric analysis based on JCLP. J. Clean. Prod. 2019, 212, 822-836. [CrossRef]

35. Paoli, F.F.; Oliveira Neto, G.C.; Lucato, W.C. Economic and environmental gains resulting from the utilization of the design for the environment (DfE). Espacios 2013, 34, 181-200.

36. Oliveira Neto, G.C.; Godinho Filho, M.; Ganga, G.M.D.; Naas, I.A.; Vendramentto, O. Princípios e ferramentas da produção mais limpa: Um estudo exploratório em empresas brasileiras. Gestão Produção 2015, 22, 326-344. [CrossRef]

37. Hangelstein, K. Globally sustainable manganese metal production and use. J. Environ. Manag. 2009, 90, 3736-3740. [CrossRef] [PubMed]

38. Zhang, H.; Hara, K.; Yabar, H.; Yamaguchi, Y.; Uwasu, M.; Morioka, T. Comparative analysis of socio-economic and environmental performances for Chinese EPIs: Case studies in Boatou, Suzhou, and Shanghai. Case Rep. 2009, 4, 263-279.

39. Gajdzik, B. Environmental aspects, strategies and waste logistic system based on the example of metalurgija. Metabk 2009, 48, 63-67.

40. Kurtagic, S.M.; Silajdzic, I.; Vucijak, B. Improvement of resource efficiency in metal industry. Alta Tech. Conviniensis 2013, 1, 25-30.

41. Santana, J.C.C.; Guerjardt, F.; Franzini, C.E.; Vanalle, R.M.; Berssaneti, F.T. Refurbishing and recycling of cell phones as a sustainable process of reverse logistics: A case study in Brazil. J. Clean. Prod. 2021, 283, 124585. [CrossRef]

42. Passarini, K.C.; Gamarra, F.M.C.; Vanalle, R.M.; Santana, J.C.C. Sewage reuse in plant irrigation and soil recovery. Inf. Technol. 2012, 23, 57-64.

43. He, F.; Wang, J.; Chen, W. Cleaner Production Assessment for Wastewater Treatment Plants Based on Back propagation Artificial Neural Network. Neuro Quantology 2018, 16, 578-585.

44. Alkoy, T.; Gonel, F. How green is my industry? The case of Turkey. World J. Sci. Technol. Sustain. Dev. 2015, 12, 119-128. 
45. Satish, J.G.; Nagesha, N. Cleaner Production: A brief literature review. Mater. Today Proc. 2018, 5, 17944-17951. [CrossRef]

46. Ferennhof, H.A.; Vignochi, L.; Selig, P.M.; Lezana, A.G.R.; Campos, L.M.S. Environmental management systems in small and medium-sized enterprises: An analysis and systematic review. J. Clean. Prod. 2014, 74, 44-53. [CrossRef]

47. Ashton, S.A.; Panedo, M.A.; Cruz, C.I.; Martin, H.M. Financing resource efficiency and cleaner production in Central America. Clean Technol. Environ. Policy 2018, 20, 53-63. [CrossRef]

48. Corral, C.M. Sustainable production and consumption systems cooperation for change: Assessing and simulating the willingness of the firm to adopt/develop cleaner technologies. The case of the In-Bond industry in northern Mexico. J. Clean. Prod. 2003, 11, 411-426. [CrossRef]

49. Yin, R.K. Estudo de Caso: Planejamento e Métodos, 5th ed.; Bookman: São Paulo, Brazil, 2015; 320p.

50. Eisenhardt, K.M. Building theories from case study research. Acad. Manag. Rev. 1989, 14, 532-550. [CrossRef]

51. Bryman, A. Social Research Methods, 5th ed.; Oxford University Press: Oxford, UK, 2016.

52. Collins, J.; Hussey, R. Business Research Methods, 2nd ed.; McGraw-Hill: New York, NY, USA, 2007; 764p.

53. Bogdan, R.; Biklen, S. Qualitative Research for Education: An Introduction to Theory and Method, 2nd ed.; Allyn and Bacon: Boston, MA, USA, 1992; 276p.

54. Oliveira Neto, G.C.O.; Sousa, W.C. Economic and Environmental Advantage Evaluation of the Reverse Logistic Implementation in the Supermarket Retail. IFIP-Adv. Inf. Commun. Technol. 2014, 439, 197-204.

55. Neto, G.C.O.; De Souza, M.T.S.; Da Silva, D.; Silva, L.A. An assessment of the environmental and economic benefits of implementing reverse logistics in the textured glass sector. Ambiente Soc. 2014, 17, 195-216.

56. De Oliveira Neto, G.C.; Shibao, F.Y.; Filho, M.G.; Chaves, L.E.C. Cleaner production: A study of the environmental and economic advantage in polymer recycling. Interciencia 2015, 40, 364-373.

57. Silva, P.C.; Oliveira Neto, G.C.; Correia, J.M.F.; Tucci, H.N.P. Evaluation of economic, environmental and operational performance of the adoption of cleaner production: Survey in large textile industries. J. Clean. Prod. 2021, 278, 123855. [CrossRef]

58. Oliveira Neto, G.C.; Leite, R.R.; Shibao, F.Y.; Lucato, W.C. Framework to overcome barriers in the implementation of cleaner production in small and medium-sized enterprises: Multiple case studies in Brazil. J. Clean. Prod. 2017, 142, 50-62. [CrossRef]

59. Pigola, A.; da Costa, P.R.; Carvalho, L.C.; Silva LF, D.; Kniess, C.T.; Maccari, E.A. Artificial Intelligence-Driven Digital Technologies to the Implementation of the Sustainable Development Goals: A Perspective from Brazil and Portugal. Sustainability 2021, 13, 13669. [CrossRef]

60. Wuppertal Institute. Table of Material Intensity of Materials, Fuels and Transport Services. Version 2. 2003. Available online: http:/ / www.wupperinst.org/uploads/tx_wibeitrag/MIT_v2.pdf (accessed on 10 March 2017). 